\title{
Science, Religion, and Politics: Issues and Challenges in Dealing with the COVID-19 Pandemic in the US and Indonesia
}

\author{
Peter Suwarno
}

Arizona State University

\begin{abstract}
Throughout human history, pandemic has created sufferings and uncertainties, leading to frantic searches for remedy scientifically and spiritually, including the current COVID-19 pandemic that has inundated the whole world. Fortunately, advances in science have helped contain many deadly deceases and made speedy progress in dealing with COVID-19 pandemic, but scientific information still clashes with those of non-scientific, religious, and political ones. The purpose of this paper is to describe the role of science, religion, and politics in how we deal with the COVID-19 pandemic in the US and in Indonesia. Using literature reviews, this study will collect data from researches, surveys and information from various media containing COVID-19 issues. This study argues that, while religions and politics play important roles in dealing with crises such as COVID-19 pandemic, evidences in science will continue to have the most prevailing contribution for the future well-being of humanity.
\end{abstract}

Keywords: Science; Politics; Religions; COVID-19; Humanity

\section{Introduction}

Humanity has experienced several epidemics, such as the European Black Death (13461353), Flu (1918-1919), Choleras (from 1817), HIV/AIDS (from 1981) and now COVID-19. People have relied on supernatural means to survive, but increasing natural investigation to address health crisis continues to generate more effective scientific discoveries, from penicillin to the recent mRNA COVID-19 vaccines. Thus, biomedical scientific researches that have benefitted human well-being increases public trust in science (Barber, 1990).

Despite this trust, science has historically faced oppositions from religious groups. It is indisputable that religions play an important role in time of the epidemics (Ogland \& Bartkowski, 2014). Karl Marx's "opiate of the masses" suggested that religions help human through difficult time, but he argued that religions divert people from focusing on the physical causes of their misery. The debates between science and religions continue, affecting policies of dealing with the COVID pandemic (Schnabel, 2021). In addition, politics plays an important role in the implementation of scientific discoveries enhanced by recent acceleration in uncontrolled information exchanges in various media, creating political polarization and conflicts on the current COVID-19 pandemic policies (Casero-Ripollés, 2020). 
The purpose of this paper is to discuss issues and challenges of addressing the COVID-19 pandemic in the US and in Indonesia by considering the interplay of science, religions and politics. It discusses the role of these three constructs in the government's efforts in resolving COVID-19 pandemic based on literature reviews, including data collection from studies, surveys and discussions from various media. Comparing the two countries in these matters will hopefully reveal not only similarities and differences, but also lessons that could be learned regarding the COVID-19 pandemic.

\section{Result and Discussion}

\subsection{Science versus Religions during epidemics}

The early $17^{\text {th }}$ century Galileo affair in Europe marked the scientific revolution manifesting the conflicts between religion and science. While the atheistic scientists and philosophers such as Richard Dawkins and Lawrence Krauss (Dawkins, 2007) believe in the incompatibility of science and religions, others, e.g. Francisco Ayala and Kenneth Miller, accept the compatibility of both (Ayala, 2000). Religious groups during an epidemic believe that epidemic is 1) part of God's judgements of human sins urging believers to pray and ask for forgiveness, and 2) attributable to the faults of the condemned others, such as the Jews during the European Black Death epidemics in 1300s. While, scapegoating also occurred in the US, e.g. blaming LGBT's sin for some miseries, and in the majority Muslim Indonesia, some blamed Chinese communists, Jews, and Christians, most still believe in prayers as a reminder of the fragility of life on Earth and of the permanent reality of God.

Conflicts between science and religion are manifested in different forms such as higher religiosity being connected to less positive views of scientific findings (Bénabou, Ticchi \& Vindigni, 2013) and strong religious beliefs being negatively correlated with biomedical advices such as vaccinations (Shelton, Snavely, De Jesus, Othus, \& Allen, 2013). Highly religious people tend to reject the morality of research and the scientists acting as if they try replace God's works (Ecklund, Scheitle, Peifer, \& Bolger, 2017). Religious groups such as White Evangelicals are against scientific-based policies, but politics becomes their main motive for rejecting government health protocols. However, although in the past Christian ministers tended to preach a pandemic as God's wrath against sinners, faith-based justifications weakened in line with the increasing evidence for rational scientific explanations, shaping the ways of dealing with human crisis, including COVID-19 (Phillips, 2020). Surveys confirm that advances in biomedical discoveries have reduced reliance on religions and increase trusting science (Pew Research Center, 2019). Religious groups accommodate scientific biomedical advances as parts of God's works, preaching "COVID-19 vaccination as God's healing power;" while maintaining religions as sources of comforting teachings on lives in the world (Ammerman 2020; Ogland \& Bartkowski 2014).

\subsection{The Interplay of Politics in Religious Views of the Pandemic}

Pew's study shows that about $96 \%$ of Indonesians believed in religious moral values and prayers to God as important parts of their lives. In the US, the Gallup Poll on church membership shows that $73 \%$ of US population are affiliated with church membership 1937 and around $70 \%$ six decades later, but religiosity in the US has significantly declined around the turn of the $21^{\text {st }}$ century. $49 \%$ of Americans think that religion is important in their life, but 
the percentage of no affiliation to any religious membership increased from $4 \%$ to $7 \%$, and for baby boomers from $7 \%$ to $13 \%$, and for Gen Xers from $11 \%$ to $20 \%$ ). Despite the significant drop in church membership, the remaining Christian members belong to a more fundamentalists groups such as the Evangelicals that have significant political power.

Since Galileo's execution by the political power of the Catholic Church and the debate of the Huxley-Wilberforce Oxford on evolution versus creation 1860 (Phillips, 2020), there has always been conflicts between science and politics. In the US, the creation versus evolution debate has enhanced important Republican versus Democrats contestation on whether religion or science is better in dealing with the world human crisis. The debates on origin of Earth, climate change, and stem cell research, have heightened the divisive political views on COVID-19 pandemic policies (Evans 2011).

\subsection{Religion, Politics, and COVID-19 in the US}

Although the US first amendment stipulates the separation of religion from state, fundamentalist religious groups continue to have strong political power. For example, the White Evangelicals' strong support for president Trump's rhetoric of ignoring the threat of COVID-19 pandemic creates a strong connection between religious nationalism and American exceptionalism, leading to conflicts between secular and religious establishments. Christian nationalism in the US has prevented its followers from accepting the historical dynamic of religion and science relationship, including the science of COVID-19 (McLaren, 2020). The more intense the religiosity of white Christians, the more likely they embrace conservative republican values and politics (McPhetres \& Zuckerman,2018), the more they downplay the COVID-19 danger (Schnabel, 2021), and the more they become part of movements that rejects the government scientific-based COVID-19 policies.

Pew's surveys show that $69 \%$ of U.S. adults (in February, 2020) and $72 \%$ of them (in May, of 2020) confirmed that they would get a coronavirus vaccine, but in September, 2020 the percentage of willingness to get the vaccine plummeted to $51 \%$ and rising again to $60 \%$ in November 2020. This is due to discursive contestation narrated in various social media between the government science-based information and the non-scientific misinformation often based on conspiracy theories. Politically, those who believe in election fraud and conspiracy theories tend to be Republicans, White Evangelicals, and less willing to mask and get a vaccine.

Pew's survey also shows that among religious groups, atheists are the most likely to say they would get a vaccine or already received one dose, while White Evangelical Protestants are the least likely. $90 \%$ of Atheists said in February that they got or would get a vaccine, while around $80 \%$ of Agnostics and $77 \%$ of Catholics said the same. The share was considerably smaller among Black Protestants (64\%) and White Evangelical Protestants (54\%). Vaccines effectively prevent severe illness, hospitalization, and death, in June of 2021, but nearly half the population remains unvaccinated and more than half of the $30 \%$ of U.S. adults stated that they will never want to get the vaccination.

The connection between religion and politics in the US explains why religions that have psychological health benefit can also hurt physical health (Schnabel, 2021). Early in the pandemic, religious people, especially Evangelical republicans tend to have less distress or concern about COVID-19 than liberals and Democrats. An example of religious resistance against COVID-19 health policies is expressed by Pastor Tony Spell of the 3,000-member Life Tabernacle Church, Louisiana who continued to hold services attended by thousands of unmasked members and who preached anti vaccine message. This is partly why some 
conservative Republican states have the highest upsurge in recent COVID-19 infection, hospitalization, and death.

Ironically, a nation with the most advanced scientific discoveries, the US is inundated with partisan religious politics of anti-science and anti-vaccine movements. The Republican leaders have helped radicalized their constituents to follow Trump's leadership that ignored the seriousness of COVID-19. Based on the rhetoric of liberty, the Republican leaders portray the government as an authoritarian regime attempting to control the people using the pandemic scheme. This include, for example, some Republican leaders who made the following statements regarding health policies of masking and vaccination: "The government imposes harmful policies of the petty tyrant of bureaucrats" (Rand Paul). "They do not respect your liberty about your choices about your healthcare... about your private life" (Ted Cruz). "Individual safety is managed everyday as a personal responsibility..." (Governor Abbots). "I see no reason to be pushing vaccine on people" (Senator Johnson).

This political apathy against government policies in the midst of uncertainties enhanced the spread of conspiracy theories, generating the portrayal of common enemies, such as COVID-19 virus as a hoax from the government to frighten the people and as a bioweapon devised in Chinese laboratory to destroy America (Douglas, 2021). This is mostly attributable to lower levels of education, searches for answers that has no clear patterns of the past experiences (van Prooijen \& van Vugt, 2018), the longing for a sense of control, anxiety, as well as the desire to have a stronger group identity for a sense of belonging, uniqueness and unity (Graeupner \& Coman, 2017). In the end, politicized conspiracy theories, hoaxes and disinformation only destroyed useful and qualified scientific evidence, making it more challenging to end the COVID-19 pandemic.

\subsection{Religion, Politics, and COVID-19 in Indonesia}

Indonesia is the world's fourth most populous nation with the highest number of Muslims, but there is no large organized religious group that rejects health protocols and vaccination. The majority Muslim communities in Indonesia usually look for guidance from their faith leaders and Islamic institutions, such as MUI's (Majelis Ulama Indonesia or Indonesian Council of Ulama) that has the authority in issuing fatwas (edicts). Although the edicts are non-binding and sometimes controversial, the majority of Indonesian Muslims tend to listen to them, giving MUI socio-political power that shapes the civil debates in the public sphere (Ricklefs, 2012).

In 2020 and 2021, the debates on COVID-19 pandemic occurred prior to the two important Islamic celebrations: the Eid al-Fitr - (End of Ramadan fasting month festival in May) and the Eid al-Adha (Islamic feast of the sacrifice in July 2020 and 2021). Some conservatives Indonesian Muslim clerics demanded that mosques be open for collective prayers and that mudik be allowed. However, such debates could be contained after leaders of MUI and other major Muslim organizations agree with the government health policies minimaxing the violations.

Fortunately, the influential MUI's edicts have been mostly supportive of government COVID-19 pandemic policies. These include worships, celebration of major religious holydays, and other rituals that must be carried out from home, following the official guidelines. On the debate of the halal (religiously permitted) status of COVID-19 vaccines, MUI supports vaccination campaign with its fatwa No 4, 2006 encouraging vaccination despite the possibility it contains haram (religiously forbidden) substances. As a matter of fact, MUI declared in a fatwa that "Vaksin Sinovac suci dan halal" (The COVID-19 Sinovac 
vaccine is holy and permitted). As a result, different from the US White Evangelicals, there has been no significant religious issue of masking or vaccination rejection. While in the US there are more vaccines than the populations willing to take them, Indonesia does not have enough vaccines for the large of number of eager citizens who want to take them.

A survey by Indikator Politik early in February, 2021 shows that 54,9\% of Indonesians were willing to get vaccination, while $41 \%$ were not sure or not willing. WHO - UNICEF survey in September, 2020 shows that COVID-19 vaccine in Indonesia is relatively higher with $74 \%$ accept and only $26 \%$ refuse. This confirms that religious moderation has help Indonesian majority Muslims to be more open to modern scientific findings including vaccination. There are only limited number of Muslim clerics that do not believe in COVID19 virus, defying any government health protocol and vaccination.

Some public figures also spread conspiracy theories or hoaxes including the COVID-19 as the efforts by the communists, Jews, and Christians trying to destroy Islam, or the COVID-19 pandemic as the scheme of the "Global Elites," including the US, UN, and WHO to create a pandemic fear, leading to the government health policies that destroy business activities and ruin the people's livelihoods. However, unlike in the US, no Indonesian major political leaders believe in the hoaxes or campaigns to refuse the government pandemic policies, partly due to government's efforts to regularly publish data create public awareness to differentiate facts from hoaxes.

\section{Conclusion}

This paper attempts to explain the interplay of three constructs: science, religion, and politics in dealing with COVID-19 pandemic challenges in the US and Indonesia. Historical evidence shows that epidemics led to spiritual practices that helped maintain mental health, but over-reliance on religions hampers creative material efforts in resolving human crisis. Humanity has increasingly relied on sciences and recent advances in biomedical science have been effective in addressing deadly deceases in the past and will eventually succeed in containing the pandemic of COVID-19.

However, politicized religious groups help produce disinformation and conspiracy theories against scientific-based government policies. US conservative religious groups such as White Evangelicals are parts of political movements that actively engage in opposition against the science and secular government, enhancing the polarization and opposition between Republicans and Democrats on masking and vaccination.

This type of religiously and politically motivated polarization does not apply in Indonesia. As a non-secular nor religious state, Indonesia has strong supports from religious leaders and institutions such as MUI that becomes part the nation's political system. With limited opposition to the scientifically based policies, the challenge in Indonesia is mainly the availability of medicines and vaccines. Unlike in the US, the Indonesian people are more concerned about their welfare and their livelihood that becomes the main reasons for defying government policies.

Religions play important roles in human mental health and psychological well-being, but human will continue to rely on science in dealing with health crisis and welfare. Therefore, people should be educated to be aware of religiously and politically loaded disinformation and hoaxes; instead, religious and political institutions should not only trust science, but also invest more time, energy and money into reputable scientific endeavors. 


\section{References}

[1] Ammerman, Nancy T. 2020. "Rethinking religion: Toward a practice approach." American Journal of Sociology 126(1): 6-51.

[2] Ayala, Francisco J. 2000. "An American Malaise: The Debate between Darwin and Christian Fundamentalism.” Historical Philosophical Life Science 22: 273-293

[3] Barber, Bernard. 1990. Social Studies of Science. New Brunswick, NJ: Transaction Publishers.

[4] Bénabou, Roland, Ticchi, DDvide, and Andrea Vindigni. 2013. Forbidden fruits: the political economy of science, religion, and growth. Working paper Papers.SSRN.com.

[5] Casero-Ripollés, Andreu (2020). "Impact of COVID-19 on the media system. Communicative and democratic consequences of news consumption during the outbreak". El profesional de la información $\quad 29 \quad$ (2), $\quad$ e290223. https://doi.org/10.3145/epi.2020.mar.23

[6] Douglas, Karen M. (2021). "COVID-19 conspiracy theories." Group Processes \& Intergroup Relations. $24 \quad$ (2): 270-275.

[7] Evans, John H. (2011). "Epistemological and moral conflict between religion and science." Journal for the Scientific Study of Religion 50(4):707-727.

[8] Dawkins. Richaed. (2007). "Should science speak to faith?" Scientific American 297(1):88-91.

[9] Graeupner, Darmaris and Alin Coman. 2017. "The dark side of meaning-making: How social exclusion leads to superstitious thinking," Journal of Experimental Social Psychology 29 (March 2017): 218-222.

[10] McPhetres, Jonathan, \& Miron Zuckerman. (2018). "Religiosity predicts negative attitudes towards science and lower levels of science literacy." PloS one 13(11), https://doi.org/10.1371/journal.pone.0207125

[11] Ogland, Curtis \& John Bartkowski. 2014. "Biblical literalism and sexual morality in comparative perspective: Testing the transportability of a conservative religious schema." Sociology of Religion 75(1):3-24.

[12] Pew Research Center. (2019). Trust and mistrust in Americans' views of scientific experts. Technical report.

URL https://www.pewresearch.org/science/2019/08/02/trust-and-mistrust-inamericansviews-of-scientific-experts/

[13] Phillips, Howard. (2020). "'17, '18, '19: religion and science in three pandemics, 1817, 1918, and 2019." Journal of Global History 15(3): 343-443.

[14] Prooijen, Jan-Willem van and Mark van Vugt. (2018). Conspiracy Theories: Evolved Functions and Psychological Mechanisms. Perspectives on Psychological Science 2018, Vol 13(6) 770-788.

[15] Ricklefs, M.C. (2012). Islamisation and Its Opponents in Java: A Political, Social, Cultural and Religious History, c. 1930 to the Present. Hawaii: University of Hawai'i Press.

[16] Schnabel, Landon. (2021). "Opiate of the masses? Inequality, religion, and political ideology in the United States." Social Forces 99(3): 979-1012. 